\title{
Estrogen and Pelvic Organ Prolapse
}

Ling Zhou ${ }^{1,2}$, Anna Junjie Shangguan ${ }^{2}$, Stacy Ann Kujawa² ${ }^{2}$, Katarzyna Bochenska ${ }^{3}$, Lanmei Zhang ${ }^{1}$, Serdar E. Bulun ${ }^{2}$ and Hong Zhao $^{2}$

${ }^{1}$ Department of Obstetrics and Gynecology, The $306^{\text {th }}$ Hospital of Chinese People's Liberation Army, Beijing, China

${ }^{2}$ Division of Reproductive Science in Medicine, Department of Obstetrics and Gynecology, Feinberg School of Medicine, Northwestern University, Chicago, USA

${ }^{3}$ Division of Female Pelvic Medicine and Reconstructive Surgery, Department of Obstetrics and Gynecology, Feinberg School of Medicine, Northwestern University, Chicago, USA

"Corresponding author: Hong Zhao, Division of Reproductive Science in Medicine, Department of Obstetrics and Gynecology, Feinberg School of Medicine at Northwestern University, 303 E. Superior Street, Suite 4-121, Chicago, Illinois 60611, USA, Tel: 3125030780; Fax: 3125030095; E-mail: h-zhao@northwestern.edu

Received date: May 06, 2016; Accepted date: June 12, 2016; Published date: June 17, 2016

Copyright: ( 2016 Zhou Ling, et al. This is an open-access article distributed under the terms of the Creative Commons Attribution License, which permits unrestricted use, distribution, and reproduction in any medium, provided the original author and source are credited.

\begin{abstract}
Pelvic organ prolapse (POP) is a multifactorial disease with a complex and largely unknown etiology and pathophysiology. Hypoestrogenemia may be one of the risk factors associated with POP. Recent studies suggest a potential role of estrogen and its receptors in the pathogenesis of POP. Here, we summarize current research regarding the relationship between estrogen and POP to establish a theoretical foundation for using estrogen in POP treatment. Estrogen plays an important role in collagen and elastin metabolism of connective tissues through down-regulating matrix metalloproteinases and increasing cystatin $\mathrm{C}$ expression. However, previous studies have shown contradictory data regarding estrogen receptor expression in patients with POP compared to non-POP controls. At this time, there is no conclusive evidence suggesting a causal role of estrogen in POP. Further welldesigned studies are necessary to illuminate both the molecular mechanisms of estrogen function and the role of estrogen in POP.
\end{abstract}

Keywords: Pelvic organ prolapse; Estrogen; Estrogen receptor; Collagen; Matrix metalloproteinases

\section{Introduction}

Pelvic organ prolapse (POP) refers to the abnormal descent or herniation of pelvic organs from their normal attachment sites or their normal positions and can involve the bladder, uterus, vagina, small bowel, and rectum. Although only 10-20\% POP patients seek care, POP affects half of all women [1]. Clinical presentation of POP can be variable, including lower back pain, painful intercourse, a feeling that something is falling out of the vagina, urinary leakage, a chronic urge to urinate, constipation, and vaginal spotting or bleeding. Even if not life-threatening, POP can significantly impact a woman's quality of life and cause disability. Wu et al. estimated that the risk of requiring surgical correction for POP by the age of 80 is $12.6 \%$ and that 9.2 million women in United States will be affected by this condition by the year $2050[2,3]$.

Contributing risk factors to the development of POP include obstetric causes such as vaginal delivery, parity and the delivery of large infants. Non-obstetric risk factors such as increasing body mass index, aging, race, chronically increased intra-abdominal pressure, and genetic factors have also been suggested. Since there is a direct correlation between the incidence of POP and aging, and circulating estrogen levels are drastically decreased in postmenopausal women, hypoestrogenemia may be a causative factor for the development of POP. Current studies have focused on the relationship between estrogen and POP to ascertain a theoretical basis for the therapeutic use of estrogen in POP.

Pelvic organs are supported by pelvic floor muscles, connective tissues, and pelvic ligaments. Dysfunction of any of these structures will reduce the support of pelvic organs, causing organs to descend onto the vagina and eventually leading to POP. Interstitial collagen, elastin, and fibroblasts are important structural constituents of pelvic connective tissues [4]. Therefore, understanding the role of estrogen in the metabolism of these components may give us new insight into the pathogenesis of POP.

\section{Estrogen and collagen}

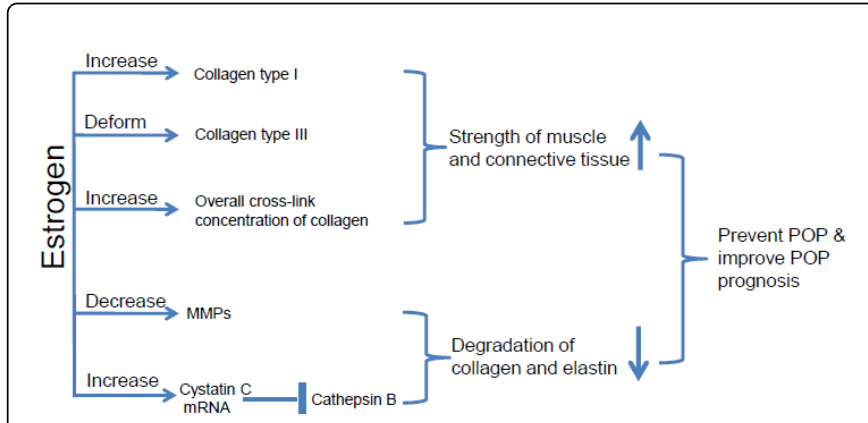

Figure 1: Estrogen and metabolism of collagen and elastin in POP. Estrogen increases the strength of muscle and connective tissue through increasing collagen type I expression and overall cross-link concentration of collagen, and deforming collagen type III. On the other hand, estrogen decreases degradation of collagen and elastin through decreasing MMPs and increasing cystatin C mRNA.

Estrogen has a profound influence on pelvic collagen synthesis. Collagen is one of the main constituents of connective tissue in the pelvis. Type I collagen is present in organized fibers and ligamentous tissue, whereas type III collagen is commonly found in loose areolar tissue. The composition of collagen subtypes differs between women 
with POP and controls. In general, expression of type III collagen, which provides weaker structural support than type I collagen, is higher in the ligaments of prolapsed uteri in comparison with ligaments of normal uteri, leading to decreased strength in the pelvic supportive ligaments [5]. Estrogen can increase type I collagen expression and deform type III collagen in fibroblasts, leading to increased muscular strength [6]. Muscle strength can also be improved by enhancing type I collagen expression in pelvic organ tissues [6]. Additionally, estrogen can also increase overall collagen cross-linking and replace aged collagen with new tissue, leading to increased tissue strength (Figure 1) [7].

Matrix collagen in connective tissue is generally degraded by matrix metalloproteinases (MMPs), which are a family of zinc-dependent endopeptidases [8-11]. MMP-1 and MMP-9 both cleave denatured collagen chains. MMP-2 can act on both intact and denatured collagens. Cathepsin B cleaves the cross-link sites of collagen during the first step of collagen degradation [12]. MMP-13 degrades fibrillar collagens and activates other MMPs to initiate degradation pathways (Figure 2) [13].

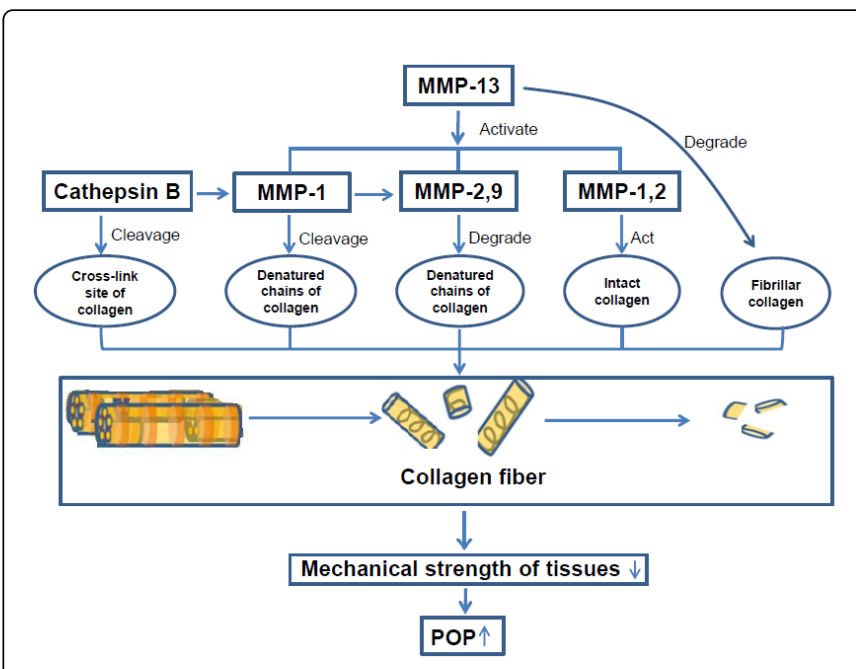

Figure 2: Degradation of collagen in POP. Matrix metalloproteinases (MMPs) degrade collagen in POP connective tissue. Increased MMPs can increase the degradation of collagen, thus decreasing the mechanical strength of tissues and leading to development of POP.

Estrogen can down-regulate MMP-9 and MMP-12 in the vaginal wall, leading to decreased collagen degradation [14]. Additionally, estrogen decreases MMP-13 proteolytic activity by activating MMP-13 fragmentation in the cell-associated ubiquitin-proteasome pathway, leading to an overall decrease in MMP-13 activity [15]. Estrogen has been shown to increase cystatin $\mathrm{C}$, an inhibitor of the protease cathepsin, in fibroblasts and smooth muscle cells of the rhesus macaque vagina [16]. Thus, estrogen inhibits collagen degradation via down-regulation of MMPs (Figure 1).

\section{Estrogen and elastin}

Elastin is also one of the main constituents of connective tissue in the pelvis. In contrast to the strength provided by collagen, elastin promotes tissue flexibility, extension, resilience, and recoil [4]. Connective tissue derived from the uterosacral ligament and vaginal wall of women with POP has been found to express lower levels of elastin $[17,18]$.

Lysyl oxidase (LOX) is a copper-dependent amine oxidase. The synthesis of mature elastin fibers requires LOX-Like 1 (LOXL1). The expression of LOXL1 mRNA in POP compared to non-POP tissues is controversial. Some studies have shown that LOXL1 mRNA expression levels in POP tissues are higher than non-POP tissues [19,20], while other studies have demonstrated opposite results [21,22]. However, after treatment with estradiol (E2), the expression of LOX family genes increases in the vagina of mice. These results indicate that $\mathrm{E} 2$ treatment could increase expression of LOX genes and suggest that E2 may be used in interventions for POP in humans [23]. Overall, the specific mechanisms of LOXL1 in the development of POP are complex and remain unclear. Further studies are necessary to elucidate the role of LOXL1 in development of POP.

Neutrophil elastase (NE) and MMP are the most important proteases involved in the proteolytic degradation of elastin [24]. Elastolytic protease activities of NE, MMP-2, and MMP-9 are increased in uterosacral ligaments of women with POP [25]. Additionally, immature elastin, mature elastin, and the elastin-degrading enzyme MMP-9 are increased in vaginal wall tissues in women with POP as compared to controls [26]. Several studies have demonstrated that estrogen can down-regulate MMPs in the vaginal wall and possibly decrease elastin degradation, suggesting a role of estrogen in elastin metabolism (Figure 1).

\section{Estrogen and fibroblasts}

Pelvic connective tissues consist of a small number of fibroblasts surrounded by an extracellular matrix (ECM). Fibroblasts remodel their surrounding matrix in response to mechanical and biochemical stimuli, which maintains the strength of the ECM. Fibroblasts derived from POP tissues respond differently to mechanical and biochemical stimuli as compared to fibroblasts from controls. Fibroblasts from POP tissues have lower contractile capacities and delayed mechanoresponses compared with non-POP site cells [27]. Furthermore, POP fibroblasts produce stiffer matrices than cells from non-prolapsed tissues. Therefore, prolapsed tissues have increased stiffness and decreased connective tissue strength, which may contribute to the development of POP $[27,28]$.

Estrogen also affects the cytoskeleton and cell morphology of fibroblasts. Estrogen therapy can suppress excessive and abnormal remodeling of fibroblasts and their cytoskeletons, thereby improving the mechanical properties of connective tissues. Thus, estrogen may maintain the integrity and function of fibroblasts and connective tissues during mechanical stretching to prevent POP and improve POP prognosis [29].

\section{Estrogen receptors}

Estrogen function is primarily mediated via specific intracellular estrogen receptors (ERs), which are members of a super-family of ligand-activated transcription factors expressed in target tissues [30]. There are two major ERs, ER $\alpha[31,32]$ and ER $\beta[33,34]$, and estrogen binds to both ERs with high affinity and specificity. The expression of $\mathrm{ER} \alpha$ and $\mathrm{ER} \beta$ is different in various target tissues. ER $\alpha$ is expressed at high levels in the uterus. In contrast, other estrogen target tissues such as the prostate [35], salivary glands [36], testis [37], ovary [38], vascular endothelium [39], smooth muscle [40], and immune system [41] have high expression of ER $\beta$. Estrogen and ERa agonists induce 
Page 3 of 6

increased collagen bundle thickening and fibronectin deposition in human skin [42]. ER $\beta$ is involved in elastin and collagen homeostasis either through transcriptional effects on elastin and collagen genes or through regulation of proteases involved in the degradation of these proteins [43]. The rapid non-genomic signaling pathways mediated by cell membrane-associated ERs have also been recognized. Various functions of ER $\alpha$ and ER $\beta$ require not only receptor-ligand binding, but also activation of downstream modulators of gene expression [44].

Estrogen induces polyphenic responses in target tissues through classic steroid receptor-mediated pathways and transactivation of Fos/Jun (AP1) mechanisms in women with POP. The specific receptor subtypes may mediate different functions of estrogen [45]. As previously mentioned, hypoestrogenemia is associated with POP, and estrogen plays an important role in collagen and elastin metabolism in connective tissues. However, ER expression levels in POP and nonPOP tissues are controversial. The distribution and function of different ERs in the pelvic floor connective tissue are elaborated below.

Grigoriadis et al. demonstrated that the expressions of both ERa and ER $\beta$ are significantly reduced in the pubocervical fascia tissues of postmenopausal women diagnosed with POP as compared with nonPOP controls [46]. Shi et al. found that levels of ERa protein are 2.2fold lower in the cervical portion of uterosacral ligaments of POP patients compared with non-POP controls. This may be mediated by post-translational control of ER $\alpha$ expression via increased expression of miR-221 and miR-222 [47]. Consistent with this finding, Other studies also found that the expression of ERa is significantly lower in the uterosacral ligaments of the POP patient group compared to the non-POP control group $(\mathrm{p}<0.0001)[48,49]$. Furthermore, data shows that expression of ER $\beta$ is lower and expression of miR-92 is higher in uterosacral ligaments of POP patients compared to non-POP controls. This suggests that ER $\beta$ protein levels are lower secondary to increased miR-92 expression [50].

Contrary to the studies described above, other studies have shown opposite findings. Dietrich et al. found that mRNA levels of both ERa $(\mathrm{p}<0.001)$ and $\operatorname{ER} \beta(\mathrm{p}=0.057)$ are higher in uterosacral ligaments from women with POP compared to non-POP controls [51]. Moreover, Zbucka-Kretowska et al. divided women into four groups to further study ER expression in vaginal walls: premenopausal women with POP, premenopausal women without POP, postmenopausal women with POP, and postmenopausal women without POP. Higher ERa and lower ER $\beta$ expression are found in premenopausal women with POP compared to premenopausal women without POP. However, ERa and ER $\beta$ expression did not differ between postmenopausal women with and without POP [52]. Another study further confirmed the majority of these findings, with the only difference being higher ER $\alpha$ expression in postmenopausal women with POP than in postmenopausal women without POP [45]. Elevated ERa expression has also been found in the cervix and levator ani. The levels of ERa in the cervix of women with POP are elevated compared to the women without POP [53]. The expression of ERa in the levator ani muscle stroma is also significantly higher in women with POP compared with age-matched asymptomatic controls [54].

Why are there conflicting results regarding ER expression in the pelvic connective tissues of women with POP? Differences in sample sizes, techniques, tissue types, menopausal status, and degree of POP may affect ER expression (Table 1) [45-58].

\begin{tabular}{|c|c|c|c|c|c|c|c|c|}
\hline & \multicolumn{2}{|c|}{ Sample size } & \multirow{2}{*}{$\begin{array}{l}\text { Menopausal } \\
\text { status }\end{array}$} & \multirow[t]{2}{*}{ Stage } & \multirow[t]{2}{*}{ Techniques } & \multirow[t]{2}{*}{ Tissues } & \multicolumn{2}{|l|}{ Results } \\
\hline & POP & Control & & & & & $E R \beta$ & \\
\hline $\begin{array}{l}\text { Grigoriadis C, et } \\
\text { al.2016 }\end{array}$ & 40 & 40 & Post & II and above & $\mathrm{IHC}$ & Pubocervical fascia & Low & Low \\
\hline Shi Z, et al. 2012 & 40 & 40 & Post & II and above & Immunoblotting IHC & $\begin{array}{l}\text { Uterosacral } \\
\text { ligaments }\end{array}$ & Low & \\
\hline $\begin{array}{l}\text { Dietrich W, et } \\
\text { al. } 2012\end{array}$ & 13 & 13 & Pre \& Post & II and III & RT-PCR & $\begin{array}{l}\text { Uterosacral } \\
\text { ligaments }\end{array}$ & High & High \\
\hline $\begin{array}{l}\text { Zbucka- } \\
\text { Kretowska M, et } \\
\text { al.2011 }\end{array}$ & $\begin{array}{l}4 \text { (Pre) } \\
12 \text { (Post) }\end{array}$ & $\begin{array}{l}5 \text { (Pre) } \\
9 \text { (Post) }\end{array}$ & Pre \& Post & uncertain & RT-PCR & Vaginal walls & High & $\begin{array}{l}\text { Low (Pre) } \\
\text { No change } \\
\text { (Post) }\end{array}$ \\
\hline $\begin{array}{l}\text { Ibeanu OA, et al. } \\
2010\end{array}$ & 14 & 28 & uncertain & uncertain & $\mathrm{IHC}$ & Cervix & High & \\
\hline $\begin{array}{l}\text { Bai SW, et al. } \\
2005\end{array}$ & 20 & 24 & Post & III and IV & Immunoblotting & $\begin{array}{l}\text { Uterosacral } \\
\text { ligaments }\end{array}$ & Low & \\
\hline $\begin{array}{l}\text { Ewies AA, et al. } \\
2004\end{array}$ & $\begin{array}{l}8 \text { (Pre) } \\
25 \text { (Post) }\end{array}$ & $\begin{array}{l}15 \text { (Pre) } \\
10 \text { (Post) }\end{array}$ & Pre \& Post & III & $\mathrm{IHC}$ & Cardinal ligaments & High & $\begin{array}{l}\text { Low (Pre) } \\
\text { No change } \\
\text { (Post) }\end{array}$ \\
\hline $\begin{array}{l}\text { Lang JH, et } \\
\text { al. } 2003\end{array}$ & $\begin{array}{l}7 \text { (Pre) } \\
18 \text { (Post) }\end{array}$ & $\begin{array}{l}12 \text { (Pre) } \\
20 \text { (Post) }\end{array}$ & Pre \& Post & I, II and III & $\mathrm{IHC}$ & $\begin{array}{l}\text { Cardinal ligaments } \\
\text { and uterosacral } \\
\text { ligaments }\end{array}$ & $\begin{array}{l}\text { Low (Pre) } \\
\text { No change } \\
\text { (Post) }\end{array}$ & \\
\hline
\end{tabular}




\begin{tabular}{|l|l|l|l|l|l|l|l|}
\hline $\begin{array}{l}\text { Copas P, et } \\
\text { al. } 2001\end{array}$ & 45 & 10 & Pre \& Post & uncertain & IHC & $\begin{array}{l}\text { Levator ani muscle } \\
\text { and the overlying } \\
\text { fascia }\end{array}$ & High \\
\hline He K, et al. 2016 & 49 & 25 & Pre \& Post & II and above & Immunoblotting IHC & $\begin{array}{l}\text { Uterosacral } \\
\text { ligaments }\end{array}$ & Low \\
\hline
\end{tabular}

Table 1: Summary of the recent studies for evaluating ER expression on POP.

Sample size: Two major problems are present in the aforementioned studies: small sample size and unbalanced groups. For instance, three studies above contain less than 10 samples either in POP group or in control group $[45,49,52]$. Small sample sizes suggest that the study findings may not be representative of and generalizable to the overall patient population. Additionally, unbalanced subject groups limit authors' ability to accurately compare subjects and controls. As an example, one study compared 45 subjects with POP to only 10 control subjects [54].

Techniques: Immunohistochemistry (IHC), immunoblotting, and/or reverse transcription-polymerase chain reaction (RT-PCR) are three major techniques used in these studies. Two studies employed RT-PCR to qualitatively detect the expression of ER mRNA [51,52], while the other studies used IHC and/or immunoblotting to detect the distribution and localization of ER proteins [45-50,53,54]. Differences in mRNA and protein levels between these techniques do not always parallel each other. As a result, utilizing different techniques makes comparison of results between studies difficult.

Tissues: Diverse tissue types such as those discussed below, have distinct ER distribution patterns and functions. Similarly, the distribution pattern and function of ERs in pelvic floor connective tissues are different.

1. Vaginal wall: ERa localizes to vaginal epithelial, stromal, and smooth muscle cells, whereas ER $\beta$ is expressed in vaginal epithelial and vascular smooth muscle cells. ERa mediates estrogen function in the vaginal epithelium such as epithelial proliferation, stratification, and cornification [55]. It has been reported that estrogen plays a role in vaginal vascular tissue through both genomic- and non-genomic-mediated mechanisms. ER $\beta$, which is located in the vascular tissue, may mediate the genomic effects of estrogen on human vaginal blood vessels [56]. Fuermetz et al. demonstrated that ERa expression is increased and that ER $\beta$ expression does not change after local estrogen administration [57].

2. Uterosacral ligament: Regardless of POP status, Dietrichet al. found that ERa is expressed in smooth muscle cells but not in endothelial cells of female uterosacral ligaments, whereas ER $\beta$ is located in endothelial cells but not in connective tissue [51].

3. Pelvic muscle: ER can be detected in the nuclei of connective tissue cells and striated muscle cells of the levator ani muscle [58].

In conclusion, the expression of ERs in the various tissue types affected by POP is diverse, leading to distinct responses to both locally produced estrogen and circulating estrogen levels.

Menopause status: After menopause, women experience a decrease in estrogen levels. Among these studies, only three studies compared the menopausal status between the study group and control group
$[45,49,52]$. In addition, ER expression is closely related to a subject's number of postmenopausal years [49]. The number of postmenopausal years should also be taken into account in future studies.

Degree of POP: Subjects in five studies were women with stage II or greater POP. The POP stage of study subjects in three studies is unknown [52-54]. In addition, the POP group of one study contained patients from every stage of POP [49]. We postulate that choosing advanced stages of POP may be more suitable for ER measurement because subtle differences in ER expression may not be detected by current technology in the early stages of the disease. It is important to note that POP stage classification in these studies was not standardized. It is plausible that ER expression may vary with different stages of POP, which could explain, in part, the controversy of ER expression in POP tissue.

\section{Progesterone receptor and androgens}

Progesterone receptor (PR): Expression of PR, which has been defined as an estrogen-regulated gene, may also be different in tissues from women with POP. Multiple studies have shown distinctive changes in PR expression levels that parallel changes in ER levels in POP patients [45,46,48,57].

Androgens: Androgens (testosterone and androstenedione) are the precursor for estrogen biosynthesis. It has been established that pelvic floor muscles are sensitive to testosterone [59]. Therefore, androgens may play a role in the development of POP. Currently, there are only a few studies exploring the relationship between androgen, androgen receptor (AR), and POP development. One study showed that serum testosterone concentrations in subjects with POP are the same compared to control groups [60]. Moreover, no papers have been archived in PubMed describing the role of locally produced androgens in the development of POP. However, AR expression in the vaginal wall and cardinal ligament of POP patients has been shown to be significantly higher than in controls $[45,60]$. Hormone replacement therapy (estradiol and cyclic norethisterone) can decrease AR expression [45]. Due to limited information, further studies are needed to define the potential role of androgens in POP development.

\section{Conclusion}

Estrogen has a profound influence on pelvic collagen metabolism, including synthesis and degradation. Estrogen also enhances the replacement of aging collagen by down-regulating MMPs and increases cystatin $\mathrm{C}$ in fibroblasts and smooth muscle cells of the vagina, leading to an overall increase in the concentration of collagen cross-links. Furthermore, estrogen affects the cytoskeleton and cell morphology of fibroblasts. The role of estrogen in pelvic floor connective tissues is unquestionable, but the role of its receptors is perplexing. At this time, estrogen receptor function remains unclear, 
and there is no conclusive evidence suggesting a causal role of estrogen in POP. In order to address this question, a well-designed clinical study should include a sufficient sample size, uniform POP classification standards, a comprehensive method to choose experimental groups, suitable techniques, and a wider selection of diverse tissue types to ensure more accurate results.

\section{References}

1. Barber MD, Maher C (2013) Epidemiology and outcome assessment of pelvic organ prolapse. Int Urogynecol J 24: 1783-1790.

2. Wu JM, Matthews CA, Conover MM, Pate V, Jonsson Funk M (2014) Lifetime risk of stress urinary incontinence or pelvic organ prolapse surgery. Obstet Gynecol 123: 1201-1206.

3. Wu JM, Hundley AF, Fulton RG, Myers ER (2009) Forecasting the prevalence of pelvic floor disorders in USA Women: 2010 to 2050. Obstet Gynecol 114: 1278-1283.

4. Liu X, Zhao Y, Pawlyk B, Damaser M, Li T (2006) Failure of elastic fiber homeostasis leads to pelvic floor disorders. Am J Pathol 168: 519-528.

5. Ewies AA, Al-Azzawi F, Thompson J (2003) Changes in extracellular matrix proteins in the cardinal ligaments of post-menopausal women with or without prolapse: a computerized immunohistomorphometric analysis. Hum Reprod 18: 2189-2195.

6. Clark AL, Slayden OD, Hettrich K, Brenner RM (2005) Estrogen increases collagen I and III mRNA expression in the pelvic support tissues of the rhesus macaque. Am J Obstet Gynecol 192: 1523-1529.

7. Jackson S, James M, Abrams P (2002) The effect of oestradiol on vaginal collagen metabolism in postmenopausal women with genuine stress incontinence. BJOG 109: 339-344.

8. Curran S, Murray GI (1999) Matrix metalloproteinases in tumour invasion and metastasis. J Pathol 189: 300-308.

9. Curran S, Murray GI (2000) Matrix metalloproteinases: molecular aspects of their roles in tumour invasion and metastasis. Eur J Cancer 36: 1621-1630.

10. Murray GI (2001) Matrix metalloproteinases: a multifunctional group of molecules. J Pathol 195: 135-137.

11. Visse R, Nagase H (2003) Matrix metalloproteinases and tissue inhibitors of metalloproteinases: structure, function, and biochemistry. Circ Res 92: 827-839.

12. Jackson SR, Eckford SD, Abrams P, Avery NC, Tarlton JF, et al. (1996) Changes in metabolism of collagen in genitourinary prolapse. Lancet 347 : 1658-1661.

13. Leeman MF, Curran S, Murray GI (2002) The structure, regulation, and function of human matrix metalloproteinase-13. Crit Rev Biochem Mol Biol 37: 149-166.

14. Rahn DD, Good MM, Roshanravan SM, Shi H, Schaffer JI, et al. (2014) Effects of preoperative local estrogen in postmenopausal women with prolapse: a randomized trial. J Clin Endocrinol Metab 99: 3728-3736.

15. Zong W, Meyn LA, Moalli PA (2009) The amount and activity of active matrix metalloproteinase 13 is suppressed by estradiol and progesterone in human pelvic floor fibroblasts. Biol Reprod 80 :367-374.

16. Slayden OD, Hettrich K, Carroll RS, Otto LN, Clark AL, et al. (2004) Estrogen enhances cystatin $\mathrm{C}$ expression in the macaque vagina. J Clin Endocrinol Metab 89: 883-891.

17. Yamamoto K, Yamamoto M, Akazawa K, Tajima S, Wakimoto H, et al. (1997) Decrease in elastin gene expression and protein synthesis in fibroblasts derived from cardinal ligaments of patients with prolapsus uteri. Cell Biol Int 21: 605-611.

18. Goepel C (2008) Differential elastin and tenascin immunolabeling in the uterosacral ligaments in postmenopausal women with and without pelvic organ prolapse. Acta Histochem 110: 204-209.

19. Kow N, Ridgeway B, Kuang M, Butler RS, Damaser MS (2016) Vaginal expression of LOXL1 in premenopausal and postmenopausal women with pelvic organ prolapse. Female Pelvic Med Reconstr Surg.
20. Jung HJ, Jeon MJ, Yim GW, Kim SK, Choi JR, et al. (2009) Changes in expression of fibulin-5 and lysyl oxidase-like 1 associated with pelvic organ prolapse. Eur J Obstet Gynecol Reprod Biol 145: 117-122.

21. Zhou Y, Ling O, Bo L (2013) Expression and significance of lysyl oxidaselike 1 and fibulin-5 in the cardinal ligament tissue of patients with pelvic floor dysfunction. J Biomed Res 27: 23-28.

22. Zhao BH, Zhou JH (2012) Decreased expression of elastin, fibulin-5 and lysyl oxidase-like 1 in the uterosacral ligaments of postmenopausal women with pelvic organ prolapse. J Obstet Gynaecol Res 38: 925-931.

23. Zong W, Jiang Y, Zhao J, Zhang J,Gao JG (2015) Estradiol plays a role in regulating the expression of lysyl oxidase family genes in mouse urogenital tissues and human Ishikawa cells. J Zhejiang Univ Sci B 16: 857-864.

24. Abe H, Okajima K, Okabe H, Takatsuki K, Binder BR (1994) Granulocyte proteases and hydrogen peroxide synergistically inactivate thrombomodulin of endothelial cells in vitro. J Lab Clin Med 123: 874-881.

25. Moon YJ, Choi JR, Jeon MJ, Kim SK, Bai SW (2011) Alteration of elastin metabolism in women with pelvic organ prolapse. J Urol 185: 1786-1792.

26. Zong W, Stein SE, Starcher B, Meyn LA, Moalli PA (2010) Alteration of vaginal elastin metabolism in women with pelvic organ prolapse. Obstet Gynecol 115: 953-961.

27. Ruiz-Zapata AM, Kerkhof MH, Zandieh-Doulabi B, Brolmann HA, Smit $\mathrm{TH}$, et al. (2014) Functional characteristics of vaginal fibroblastic cells from premenopausal women with pelvic organ prolapse. Mol Hum Reprod 20: 1135-1143.

28. Ruiz-Zapata AM, Kerkhof MH, Ghazanfari S, Zandieh-Doulabi B, Stoop $\mathrm{R}$, et al. (2016) Vaginal fibroblastic cells from women with pelvic organ prolapse produce matrices with increased stiffness and collagen content. Sci Rep 6: 22971.

29. Wang S, Zhang Z, Lu D, Xu Q (2015) Effects of mechanical stretching on the morphology and cytoskeleton of vaginal fibroblasts from women with pelvic organ prolapse. Int J Mol Sci 16: 9406-9419.

30. Sarff M, Gorski J (1971) Control of estrogen binding protein concentration under basal conditions and after estrogen administration. Biochemistry 10: 2557-2563.

31. Green S, Walter P, Kumar V, Krust A, Bornert JM, et al. (1986) Human oestrogen receptor cDNA: sequence, expression and homology to verb-A. Nature 320: 134-139.

32. Greene GL, Gilna P, Waterfield M, Baker A, Hort Y, et al. (1986) Sequence and expression of human estrogen receptor complementary DNA. Science 231: 1150-1154.

33. Kuiper GG, Enmark E, Pelto-Huikko M, Nilsson S, Gustafsson JA (1996) Cloning of a novel receptor expressed in rat prostate and ovary. Proc Natl Acad Sci USA 93: 5925-5930.

34. Mosselman S, Polman J, Dijkema R (1996) ER beta: identification and characterization of a novel human estrogen receptor. FEBS Lett 392: 49-53.

35. Weihua Z, Makela S, Andersson LC, Salmi S, Saji S, et al. (2001) A role for estrogen receptor beta in the regulation of growth of the ventral prostate. Proc Natl Acad Sci USA 98: 6330-6335.

36. Valimaa H, Savolainen S, Soukka T, Silvoniemi P, Makela S, et al. (2004) Estrogen receptor-beta is the predominant estrogen receptor subtype in human oral epithelium and salivary glands. J Endocrinol 180: 55-62.

37. Makinen S, Makela S, Weihua Z, Warner M, Rosenlund B, et al. (2001) Localization of oestrogen receptors alpha and beta in human testis. Mol Hum Reprod 7: 497-503.

38. Cheng G, Weihua Z, Makinen S, Makela S, Saji S, et al. (2002) A role for the androgen receptor in follicular atresia of estrogen receptor beta knockout mouse ovary. Biol Reprod 66: 77-84.

39. Lindner V, Kim SK, Karas RH, Kuiper GG, Gustafsson JA, et al. (1998) Increased expression of estrogen receptor-beta mRNA in male blood vessels after vascular injury. Circ Res 83: 224-229.

40. Barchiesi F, Jackson EK, Imthurn B, Fingerle J, Gillespie DG, et al. (2004) Differential regulation of estrogen receptor subtypes alpha and beta in 
Citation: Zhou L, Shangguan AJ, Kujawa SA, Bochenska K, Zhang L, et al. (2016) Estrogen and Pelvic Organ Prolapse. J Mol Genet Med 10: 221. doi: $10.4172 / 1747-0862.1000221$

Page 6 of 6

human aortic smooth muscle cells by oligonucleotides and estradiol. Clin Endocrinol Metab 89: 2373-2381.

41. Shim GJ, Wang L, Andersson S, Nagy N, Kis LL, et al. (2003) Disruption of the estrogen receptor beta gene in mice causes myeloproliferative disease resembling chronic myeloid leukemia with lymphoid blast crisis. Proc Natl Acad Sci USA 100: 6694-6699.

42. Aida-Yasuoka K, Peoples C, Yasuoka H, Hershberger P, Thiel K, et al (2013) Estradiol promotes the development of a fibrotic phenotype and is increased in the serum of patients with systemic sclerosis. Arthritis Res Ther 15: R10.

43. Koehler KF, Helguero LA, Haldosen LA, Warner M, Gustafsson JA (2005) Reflections on the discovery and significance of estrogen receptor beta. Endocr Rev 26: 465-478.

44. Ponisovskiy MR (2011) Driving mechanisms of passive and active transport across cellular membranes as the mechanisms of cell metabolism and development as well as the mechanisms of cellular distance reactions on hormonal expression and the immune response. Crit Rev Eukaryot Gene Expr 21: 267-290.

45. Ewies AA, Thompson J, Al-Azzawi F (2004) Changes in gonadal steroid receptors in the cardinal ligaments of prolapsed uteri: immunohistomorphometric data. Hum Reprod 19: 1622-1628.

46. Grigoriadis C, Hassiakos D, Bakas P, Tympa A, Panoulis C, et al. (2016) Effect of gonadal steroid receptors alterations on the pathophysiology of pelvic organ prolapse and urinary incontinence. Minerva Ginecol 68: $37-42$.

47. Shi Z, Zhang T, Zhang L, Zhao J, Gong J, et al. (2012) Increased microRNA-221/222 and decreased estrogen receptor alpha in the cervical portion of the uterosacral ligaments from women with pelvic organ prolapse. Int Urogynecol J 23: 929-934.

48. Bai SW, Chung DJ, Yoon JM, Shin JS, Kim SK, et al. (2005) Roles of estrogen receptor, progesterone receptor, p53 and p21 in pathogenesis of pelvic organ prolapse. Int Urogynecol J Pelvic Floor Dysfunct 16: 492-496.

49. Lang JH, Zhu L, Sun ZJ, Chen J (2003) Estrogen levels and estrogen receptors in patients with stress urinary incontinence and pelvic organ prolapse. Int J Gynaecol Obstet 80: 35-39.

50. He K, Niu G, Gao J, Liu JX, Qu H (2016) MicroRNA-92 expression may be associated with reduced estrogen receptor betal mRNA levels in cervical portion of uterosacral ligaments in women with pelvic organ prolapse. Eur J Obstet Gynecol Reprod Biol 198: 94-99.

51. Dietrich W, Elenskaia K, Obermayr E, Horvat R, Mayerhofer K, et al. (2012) Relaxin and gonadal steroid receptors in uterosacral ligaments of women with and without pelvic organ prolapse. Int Urogynecol J 23: 495-500.

52. Zbucka-Kretowska M, Marcus-Braun N, Eboue C, Abeguile G, Wolczynski S, et al. (2011) Expression of estrogen receptors in the pelvic floor of pre- and post-menopausal women presenting pelvic organ prolapse. Folia Histochem Cytobiol 49: 521-527.

53. Ibeanu OA, Chesson RR, Sandquist D, Perez J, Santiago K, et al. (2010) Hypertrophic cervical elongation: clinical and histological correlations. Int Urogynecol J 21: 995-1000.

54. Copas P, Bukovsky A, Asbury B, Elder RF, Caudle MR (2001) Estrogen, progesterone, and androgen receptor expression in levator ani muscle and fascia. J Womens Health Gend Based Med 10: 785-795.

55. Buchanan DL, Kurita T, Taylor JA, Lubahn DB, Cunha GR, et al. (1998) Role of stromal and epithelial estrogen receptors in vaginal epithelial proliferation, stratification, and cornification. Endocrinology 139: $4345-4352$.

56. Fu X, Rezapour M, Wu X, Li L, Sjogren C, et al. (2003) Expression of estrogen receptor-alpha and -beta in anterior vaginal walls of genuine stress incontinent women. Int Urogynecol J Pelvic Floor Dysfunct 14: 276-281.

57. Fuermetz A, Schoenfeld M, Ennemoser S, Muetzel E, Jeschke U, et al. (2015) Change of steroid receptor expression in the posterior vaginal wall after local estrogen therapy. Eur J Obstet Gynecol Reprod Biol 187: 45-50.

58. Smith P, Heimer G, Norgren A, Ulmsten U (1993) Localization of steroid hormone receptors in the pelvic muscles. Eur J Obstet Gynecol Reprod Biol 50: 83-85.

59. Bhasin S, Taylor WE, Singh R, Artaza J, Sinha-Hikim I, et al. (2003) The mechanisms of androgen effects on body composition: mesenchymal pluripotent cell as the target of androgen action. J Gerontol A Biol Sci Med Sci 58: M1103-1110.

60. Chen YS, Hua KQ (2008) Expression of androgen receptor in the vaginal wall and cardinal ligament of patients with pelvic organ prolapse. Zhonghua Yi Xue Za Zhi 88: 2920-2923. 